\title{
Chapter 14. The Cultural Construction of Rank, Identity and Ethnic Origins in the Sulu Archipelago ${ }^{1}$
}

\section{Charles O. Frake}

Hierarchy is a feature of social systems whereby a ranking is attributed to socially-defined subjects of discourse. Ordinarily we think of these ranked subjects as individuals. But the rank of an individual as a subject vis-à-vis some other individual must be defined in terms of a field of scope of that rank. Thus I might rank very high within my department but, because of my department's low rank within the university, I am scorned by the dean and ignored by the provost. Yet because of my university's high rank among universities, I am accorded deference by my colleagues elsewhere in academia who are, fortunately, unaware of my dean's contempt. Whether it is better to be a big fish in a little pond or a little fish in a big pond depends on the waters in which one aspires to swim. In either case, our aspirations must take account of the rank of our pond in the field of ponds. Ponds, the social fields encompassing individuals, are also subjects of attributed rank. Where do these attributions come from? How does it come to be decided whether my pond, my department, my university, my profession, my country, is better than yours. This paper argues that, however the ranking of ponds comes about in the historical particulars of a given case, that process is constitutive of the very ponds it ranks. If it were not for the differentiation of social fields that social hierarchy requires, we would perhaps all be swimming in a common ocean.

It is with the cultural construction of the social fields of hierarchy that this study is concerned. I examine this process among Moslem Filipinos in the region of the Sulu Archipelago and the Zamboanga Peninsula of southwestern Mindanao in the Philippines. To make the topic manageable, I ignore the region's important links with Borneo to the west and with central Mindanao to the east. ${ }^{2}$ Even more seriously, I will largely ignore the parallel social system of Christian Filipinos in the same region, recognizing that the violent conflict between these two systems over the past 400 years has done much, and at this very moment is doing much, to shape each of them.

A prominent attribute of the ethnology of the Sulu region is that it is very "ethnic". Ethnologists happily find that their "tribes" for the most part come already equipped with well accepted names, distinct languages, colourful costumes, varied settlement patterns, contrasting roof slopes, distinctive dance styles, and so on. The ranking of ethnonyms, names for ethnic groups, and their 
attribution to specific persons and communities are prominent themes in the discourse of Sulu's Moslems. This ranking provides a convenient place to begin our examination. Table 1 presents a list some of the Sulu ethnonyms in rough rank order - rough because the order is subject to local negotiation and reinterpretation. The table also attempts to display some the complexities of ethnic naming, simplifying greatly in order to avoid even clumsier graphic devices. A fundamental distinction, shown in the table by italics, separates names used in self-identification (deutsch) from names attributed by outsiders ("German"). Terms of self-identification may show a further distinction, not marked in the table, of inclusive self naming ("my fellow Americans") as opposed to exclusive self naming ("Unlike you Mexicans, we North Americans ..."). Among attributed terms one must distinguish between those internal to the local system of discourse from those externally imposed by outsiders, in this case central government authorities, journalists, movie producers, missionaries, and, of course, anthropologists. Internal attributed naming may vary depending on whether the naming is being done face to face ("You Germans ...") or not ("Those Krauts ..."). The use of some ethnic names, however, can be free of these complexities. These unproblematic names do not vary with user or context.

We begin our examination of ethnic naming in Sulu with the several unproblematic names listed in Table 1. Not uninterestingly, they occur at the top and the bottom of this display of ethnic hierarchy. The heights to which one can aspire as well as the depths beyond which no one fear sink are well marked. It is the more muddled middle grounds that provide room for manœuvre. At the top we find the Tausug, a people remarkably well demarcated from all those about and below them. We can best see what sets them apart as people of high rank by comparing them with the people at the bottom of heap, the Subanun of the mountainous interior of Zamboanga. (The Subanun are actually at the bottom of two heaps: that of the Christian as well as of the Moslem social orders.) The most obvious contrast, both to locals and to outside investigators, is that of religion. The Tausug have religion in the form of official Islam with all its accoutrements: mosques, Mecca pilgrims, religious teachers, religious tracts in Arabic script, pig-free homesteads, and toddy-free markets. True, in purity of faith, they rank, even in their hardly humble eyes, below the Malay to the east in singapura, and, of course, to the Arab still further to the east in makka. But within Sulu, no one else can challenge their religious credentials. The Subanun, by contrast, have, in local eyes, no religion at all. They are pagans (or, even worse, recently converted Christian protestants), pork eaters, and rice-wine imbibers. The Tausug are linked by name to the economic and political centre of Sulu, the island of Jolo. That island has been an entrepôt linking the tropical sources of spices, forest products, and maritime delicacies to China since well before the coming of Islam. Wherever a Tausug might live, he or she "comes from" the historic central place of Sulu. He or she is a person (tau) of Jolo 
$(s u(l) u g){ }^{3}$ A Subanun's place, on the other had, is simply suba' 'upstream.' The name, meaning upstream person, or hick, is of external origin. It is an ethnonym of a type common in Island Southeast Asia, lumping all the people of the interior, the mountains, and the upstream regions in one category as opposed to the more civilized people of the coasts and lowlands. Yet it is a distinctive name and, fortuitously in this case, it does denote a cultural and linguistic entity. ${ }^{4}$ Unlike the Tausug language, which is remarkably homogeneous throughout its range, Subanun exhibits sufficient dialectal diversity that its extreme variants border on mutual unintelligibility. Compounding the markers of Subanun low status is their reputation for pacifism which stands in marked contrast to the notorious fierceness of the Tausug. This reputation which seems by all accounts, historic and contemporary, to be well merited, cannot be explained simply as a result of Subanun marginality to the centres of power and wealth. Other marginal pagans of the islands, the Ifugao, the Ilongot and the Iban have firmly established reputations as headhunting savages.

Table 1. Some ethnonyms of Sulu and Zamboanga (in rough rank order)

\begin{tabular}{|c|}
\hline Tausug \\
Yakan \\
(sama) balangingiq \\
sama + 'place name' \\
"Samal" \\
"'floater"' \\
sama + 'true' \\
sama + 'sea' \\
"Sama(I) 'to be spit on"' \\
"Bajao" \\
sama + 'land' \\
"Kalibugan" \\
kalibugan \\
Subanun
\end{tabular}

Key: Unproblematic ethnonym

self identification

"Attributed identification"

'English gloss of local term'

"'English gloss of local attributed identification"”

Both the Subanun and the Tausug share in their lexicon a full inventory of Austronesian, Sanskrit, Persian and Arabic titles. Both groups can easily people 
their stories with timu'ays, panglimas, datus, rajas, maharajas, nakuras, sarifs and sultans. But only the Tausug can ordinarily confront such characters in their daily lives. The Tausug see themselves, and are viewed by others (including their ethnographers), as a stratified society with a hereditary titled nobility headed by a ruling sultan. Western scholarship typically reflects the Tausug view of a system of named titles as actors: "A Tausug datu would authorize a panglima to conduct a raid ... The panglima then selected the nakhoda or captain, who recruited his own crew. The crew members consisted of ... Balangingi" (Gibson 1990:6). In ideology the Tausug are masters of a single political state, ruling over all the peoples of the archipelago. Actual political structure is much more chaotic and contested, but there is a structure to discern in practice as well as in discourse (see Kiefer 1969). The Subanun, on the other hand, have never had any pretensions at political unity (Frake 1980:83-103). Economic centrality, militancy, internal stratification and a semblance of political unity mark the Tausug as high rank; marginality, pacifism, egalitarianism and absence of political coherence reveal the low position of the Subanun.

Both groups, the highest and the lowest, are, however, marked off by clear ethnic distinctiveness. No account of Philippine "tribes", from the sixteenth century to the present, fails to list both the Subanun and the Tausug and to note their relative worth. ${ }^{5}$ It is in the middle ranks of the ethnic hierarchy that the distinctiveness of peoples becomes obscure and their ranking contested.

Located both geographically and socially between the Tausug of Jolo island and the Subanun of the mountains of Zamboanga are peoples variously sorted out from a pool of speakers of a distinct set of closely related languages and dialects here labelled "Samalan". The linguistic diversity within this group is considerable, but the boundaries between a Samalan language and Tausug on the one hand or Subanun on the other are quite apparent to locals as well as to investigators. Most Samalan speakers identify themselves as sama. I will use the name "Sama" for those who so identify themselves and the term "Samalan" for the language group. ${ }^{6}$ Whether or not a Samalan speaker is ethnically a "Sama" is a matter of local negotiation. To the Tausug, and in the ethnographic literature, most are "Samal". To Combés, the seventeenth century Jesuit historian of Mindanao, they were "Lutao", literally "floaters" (Combés 1897).

The Sama, unlike the Tausug and the Subanun are associated with the sea. They live along the shores of the islands of the archipelago and on the peninsula. In spite of the alleged romance of maritime life, making one's living from the sea does not confer high rank in Sulu no more than anywhere else in the modern world. Most Sama augment fishing and marine-gathering with commercial coconut cultivation and some subsistence agriculture. Many engage in trade, including quite profitable smuggling. There is considerable diversity among them in economic standing and political power. Amongst themselves, the Sama 
differentiate ethnic identity according to provenance - where one can claim to "come from". There are sama tagtabun, sama ubian and even, near a gasoline storage facility on the outskirts of Zamboanga City, sama mobilgas. Some locales rank higher than others, proximity to economic and political centres being a factor but, even more important, is something that might be called place-name notoriety. One of the highest ranking places in all the archipelago is, in fact, an uninhabited stretch of coral between Jolo and Basilan called Balangingi'. That is a name which, to judge from nineteenth century Spanish, Dutch and English accounts, struck terror in the hearts of all who ventured near the Sulu Sea. The Balangingi' were the most notorious pirates of Sulu. Their island base was finally demolished by the Spanish and the power of the pirates broken. But the notoriety and prestige of the name has continued. Most Sama in Eastern Sulu and Zamboanga who are not obviously from somewhere else, claim to be sama balangingi'. During the nineteenth century their notoriety was such that they were "Balangingi"' pure and simple. They had, by military prowess and fierce reputation climbed out of Sama status. Now they are clearly Sama again, but they are at least Sama of high rank among Sama: big fish in a lesser pond (Geoghegan 1975; Rutter 1986; Barrantes 1878; Montero y Vidal 1888; Warren 1981; Pallesen 1985).

Another group of Samalan speakers did, in fact succeed in climbing out of Sama status. In seventeenth century records the Samalan speakers of Basilan Island, off the tip of the Zamboanga Peninsula, are identified as "Sameacan", i.e. sama yakan (Combés 1897). Shortly thereafter, and down to this day, they have been known simply as "Yakan". The Yakan have worked hard at not being Sama. Like the Balangingi' they built a reputation for fierceness - but on land rather than at sea. The Yakan, in early accounts are recorded not as pirates, but as notorious bandits. The Yakan have shunned the sea, changed their costumes, altered their roof slope, rescored their music, and stopped dancing. They have fought off Sama pirates, Tausug raiders, and Christian settlers. ${ }^{7}$ In spite of the obvious Samalan affinities of their language, the Yakan are everywhere acknowledged to be a distinct ethnic group with distinct origins from the Sama. The Yakan have climbed above Sama identity but still fall below the Tausug. Their notoriety is geographically restricted, their political integration more feeble, their claim to titles on shakier grounds. Most of all, the markedness of their ethnicity casts suspicion on the purity of their Islam (Frake 1980:175-252).

One can not only climb out of Sama identity, one can fall out. Some Samalan-speakers have been so identified with the sea that they are considered to be boat-dwelling sea nomads with no local provenance. Having no Mosques, their Islam status becomes suspect. They are poor and powerless enough to border on being outcasts in the Sulu hierarchical system. Although they call themselves "true" Sama (sama to'ongan), outsiders call them a variety of derogatory terms such as "Sama to be spit upon". In the ethnographic literature, 
as well as among local Christians, they have a distinctive label: they are the "Bajao", a term also applied by outsiders to Samalan speaking communities scattered along the Borneo and Eastern Indonesian coasts. The use of "Bajao" in the Philippines represents an unusual case of over-differentiation by outsiders. One expects outsiders to overlook internally recognized boundaries. Among Sulu Moslems, these maritime Sama, called Bajao by Christian and academic outsiders, are everywhere acknowledged to be Sama or "Samal", albeit of the lowest sort.

Finally, there are Samalan speakers who have disappeared altogether as an ethnic identity. These are swidden agriculturists, living much as the Subanun, in the mountains of the southern Zamboanga Peninsula. They are nowhere listed in any inventory of named ethnic groups, thus the "empty string" symbol (" ") that represents their externally attributed ethnonym in Table 1. They consider themselves sama, but outsiders typically confuse them with Islamicized Subanun, the "Kalibugan". 8 Essentially they are nobodies, a status not without adaptive merits in the political and military arena of the southwestern Philippines (Pallesen 1985; Frake 1980:325).

How did the Tausug achieve their position of ethnic distinctiveness at the top of the Sulu hierarchy? Their own story is that they were the original inhabitants of Jolo island. The Sama came in later from Johore, accepting subservient status in turn for the right to settle among the islands. The Tausug gave religion and civilization to these sea nomads. This myth of Sama origins as external migrants wandering in by sea from Johore has a firm place not only in local ethnohistory but also in the historical literature (Saleeby 1908). Here is a recent version presented as history by a Western scholar: "One recurrent pattern in Southeast Asian history was an alliance between ethnic Bajau, or sea nomads, and a dominant ethnic group such as Malays, Bugis, or Tausug. The Bajau were originally fishers and gatherers occupying the Riau archipelago off the east coast of Sumatra, who lived their lives on boats. In the course of time, they spread up the west coast of Thailand, to the southern Philippines, and perhaps even as far as southern China" (Gibson 1990:7). It is easy to show on linguistic grounds that this myth inverts historical fact. The Tausug language is clearly intrusive to Sulu, whereas the locally well diversified Samalan languages first differentiated within the Sulu archipelago and then spread outward from there to Borneo, eastern Indonesia, and to one island in the central Philippines. Tausug closely affiliates with the languages spoken geographically far away on the northeast coast of Mindanao. It is very obviously a member of the closely-related Bisayan group of central Philippine languages, all of whose speakers are today Christian Filipinos. The linguist Kemp Pallesen (1985) has presented a well documented argument that before the appearance of the Tausug language, Samalan-speaking traders of Jolo had established trading stations in northeast Mindanao where they had intermarried with women speaking Bisayan languages. Enough of these 
women came back to Jolo that their language was established as a second language there. As the people of Jolo became more prosperous and powerful they created an identity for themselves that separated them from their Samalan-speaking kin. The new language provided a clear marker of that identity. It became the distinctive language of the Tausug. Whether or not one accepts this particular account of the formation of Tausug identity, one cannot deny that the identity was constructed and maintained locally as part of a struggle by individuals and groups to affirm and maintain high rank in a region-wide discourse of hierarchy (cf. Brown 1973).

Figure 1 presents a display of the dimensions of this discourse. The subject of the discourse is the ranking of ethnonyms, names for peoples. The attribution of these names to specific individuals and communities and the use of these names as self-identification asserts that these individuals and communities display the characteristics appropriate to the name. The Tausug display the attributes of high status: Islam, centrality in the political-economic systems; militancy; and a distinctive non-Samalan language of their own. At the bottom the Subanun are pagan, peripheral, docile, are linguistically distinct from the Samalan speakers above them. Samalan-speakers can raise their status by displays of militancy and economic power. They fall in status by being seen as geographically peripheral to the centres of power, either on land or at sea, and by displaying in behaviour the docility appropriate to a marginal people. Adherence to Islam, however, provides a firm bottom line to the descent of any Samalan-speaker and warrants, for self-identification at any rate, the ethnonym sama.

Before ending our story, note should be taken of the ethnic labelling that marks the Moslem-Christian boundary in the southern Philippines. Since the first Spanish encounters with them, the Philippine Moslems have been known to Philippine Christians as "Moros". That term has been used as an ethnic group label not only by local Christians but by outside officials and scholars down to the present. A US Department of Army poster commemorating an attack by US Troops on a Jolo bastion in 1913 thus describes the Tausug defenders whose slaughter is graphically depicted: 


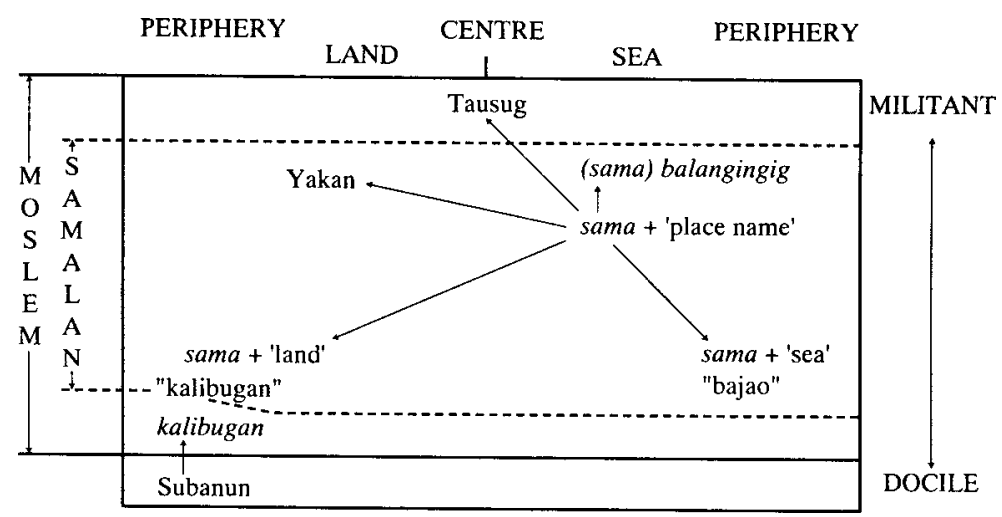

Figure 1. Dimensions of hierarchy in Sulu and Zamboanga.

Knocking out the Moros, the U.S. Army in Action: The four-day battle of Bagsak Mountain on Jolo Island in the Philippines took place from 11 to 15 July 1913. Americans of the 8th Infantry and the Philippine Scouts, personally led by Brigadier General John J. Pershing, brought to an end years of bitter struggle against the Moro pirates. These Jolo men, outlaws of great physical endurance and savage fighting ability were well organized under their Datus or chiefs ... The U.S. Army .45-caliber pistol was developed to meet the need for a weapon with enough striking power to stop fanatical charges of lawless Moro tribesmen in hand-to-hand fighting (Department of the Army 1963). ${ }^{9}$

The traditional use of "Moro" by outsiders, apart from carrying derogatory connotations, served to obscure the very real cultural and linguistic differences among Philippine Moslems (Frake 1980:314-318). The Moslems of course reciprocated with an epitaph of their own: bisaya', a term which Moslems take to mean both Filipino Christian and "slave".

With the escalation of conflict between Moslems and the Philippine government in recent decades, Moslem political and military leaders have adopted a strategy now familiar in ethnic conflict. They have taken an externally applied slur as their own self-identification, a tactic aimed on emphasizing the common historical experience of all Philippine Moslems as victims of the slurrers. The "Moro National Liberation Front" (MNLF) was formed in the 1970s by a Tausug intellectual. Its military arm titled itself the "Bangsa Moro Army" (BMA) ("Bangsa", from Malay, means "nation", "identity", "rank" in all "Moro" languages.) As a symbol of unity, however, "Moro" has had questionable success. The word has, in fact, fostered a whole new set of divisive ethnonyms. Along with the MNLF and the BMA, there arose the MILF, MNLFR, MIM, BMLO, MRO and MNRDF. All of these acronyms contain " $\mathrm{M}$ " for "Moro" and are based on English (MNRDF, for example is the "Moro National Revolutionary Democratic 
Front"), the only common language of the "Moros" (the southern Philippines is outside the scope of the use of Malay as a lingua franca). These divisions reflect conflicts along ethnic lines, especially between Tausug and Central Mindanao Moslems, along ideological lines between Communist and Islamicist, and along lines of political orientation between traditionalist and modernist (Cayongcat 1986; George 1980). The game of labelling and thereby constituting identities in the discourse of political practice is still very much alive among the Moslems of the southern Philippines.

The history of hierarchy peculiar to Sulu has something in general to tell us about the interconnections between horizontal and vertical social differentiation in human society. But I tell this story on this occasion on the grounds that all its actors speak Austronesian languages. Does that make any difference? In talking about hierarchy in our various Austronesian-speaking societies, are we saying anything "Austronesian"? Certainly the fact that members of two societies speak languages of the same family says nothing, per se, about the forms of their society. After all the Hindus and the Western Europeans, by conventional anthropological wisdom, are supposed to have diametrically opposed ideologies of hierarchy - yet they both speak languages of a common family. It is true that, among language families, there is something historically unique about Austronesian. The wide, purely insular, distribution of these languages as well as the parallel distribution of a distinctive agricultural complex both point to a shared cultural heritage among Austronesian-speakers that goes beyond linguistic affiliation. But is that heritage likely to lie behind any contemporary commonalities in systems of social hierarchy? If that is to be our argument, we must show the common historical experiences relevant to the shaping of hierarchical systems that Austronesian-speakers shared. I do not think that can be done. It is not enough to point out how the hierarchical system of one Austronesian-speaking society shares similarities with another Austronesian-speaking society at the other end of the Pacific. (Comparisons are in fact usually made between Island Southeast Asia and Polynesia, ignoring all that lies inbetween, both geographically and temporally.) One could just as easily pick out utterly dissimilar cases within the Austronesian-speaking world. Alternatively, by judicious selection of cases - focusing on the Subanuns and Hanunóos of the Austronesian world - one could just as easily argue that the fundamental Austronesian ethos has been egalitarian rather than hierarchical, diffuse rather than centric, and pluralistic rather than dualistic. Hierarchy, whatever one means by it, is not a simple, contextually arbitrary form transmitted across generations like the word mata for "eye"; it is a complex socio-cultural arrangement, constantly changing in adaptation to local socio-cultural contexts. One word for "eye" works as well as another in any context - so why not call it mata? - but one system of hierarchy definitely does not work as well as another in any circumstance. Changing social, political and ecological 
circumstances, in other words, "history" shapes hierarchical forms. The historical experiences of the western Austronesian world, peoples taking over islands already inhabited, replacing all existing languages, and then becoming enmeshed in the vortex of trade and conflict among old world civilizations, were opposed in almost every respect to those of the isolated eastern islands of Polynesia, as free of outside contact as any communities could be. If there are similarities between the hierarchical systems of Polynesia and those of Island Southeast Asia, as have been commonly proposed, then they can only be convergences of form arising from utterly dissimilar causes. It is difficult to see how sharing an Austronesian language could have anything to do with it. 


\section{References}

Barrantes, Vincente

1878 Guerras piráticas de Filipinas contra mindanaos y joloanos. Madrid: M.G. Hernandez.

Brown, D.E.

1973 Hereditary rank and ethnic history: an analysis of Brunei historiography. Journal of Anthropological Research 19:113-122.

Cayongcat, Al-Rashid I.

1986 Bangsa Moro people in search of peace. Manila: GRAPHICOM.

Combés, Francisco

1897 Historia de Mindanao y Jolo (1667). W.E. Retana (ed.). Madrid: Viuda de M. Minuesa.

Department of the Army

1963 Knocking out the Moros: the U.S. Army in action. Department of the Army Poster No. 21-48. Washington, DC: U.S. Government Printing Office.

Frake, Charles

1980 Language and cultural description. Stanford: Stanford University Press.

Geoghegan, William

1975 Balangingi. In Frank M. LeBar (ed.) Ethnic groups of insular Southeast Asia. vol. 2, Philippines and Formosa. New Haven: Human Relations Area Files Press.

George, T.J.S.

1980 Revolt in Mindanao: the rise of Islam in Philippine politics. Kuala Lumpur: Oxford University Press.

Gibson, Thomas

1990 On predatory states in Island Southeast Asia. Canberra: Department of Anthropology Comparative Austronesian Project, Research School of Pacific Studies, The Australian National University.

Kiefer, Thomas M.

1969 Tausug armed conflict: the military activity in a Philippine Moslem society. Chicago: University of Chicago Department of Anthropology.

1972 The Tausug: violence and law in a Philippine Moslem society. New York: Holt, Rinehart \& Winston.

Montero y Vidal, Jose 
1888 Historia de la piraterí a malayo-mahometana en Mindanao, Joló y Borneo. 2 vols. Madrid: M. Tello.

Pallesen, Kemp A.

1985 Culture contact and language convergence. Manila: Linguistic Society of the Philippines.

\section{Rutter, Owen}

1986

The pirate wind: tales of the sea-robbers of Malaya. Singapore: Oxford University Press [reprint of 1930 edition].

Saleeby, Najeeb M.

1908 The history of Sulu. Manila. Bureau of Science.

Sather, Clifford

1984 Sea and shore people: ethnicity and ethnic interaction in Southeastern Sabah. Contributions to Southeast Asian Ethnography 3:3-27.

Verschuer, F.H. van

1883 De Badjo's. Tijdschrift van het Aardijkskundig Genootschap 7:1-7.

Warren, James F.

1981 The Sulu zone, 1768-1898. Singapore: Singapore University Press.

\section{Notes}

1 This paper represents a reworking of an earlier study (Frake 1980) rethought, updated, and oriented toward issues of hierarchy. It depends ultimately on field work conducted in the region from 1953 to 1972, ending with the year of the imposition of martial law in the Philippines. New information is forthcoming thanks to the just completed study of the Sama of westernmost Sulu by Patricia Horvatich of Stanford University. I have benefited by her work, as well as by comments from participants in the conference on hierarchy in the Austronesian-speaking world held at the Research School of Pacific Studies, Australian National University and from audiences of presentations of this material at the University of the Philippines and Cornell University. Clifford Sather, an expert on the peoples of the wider region of this study, has provided especially useful suggestions.

2 Sather (1984) provides a comparable discussion of ethnicity among related and interconnected peoples to the west in Sabah.

3 "Jolo" is a hispanicization of sulug (or Sama suluk) dating from when Philippine Spanish " $\mathrm{j}$ " represented a sound closer to [s] than to [h], its current pronunciation in the Philippines. The contrast between "Sulu" as the name for the archipelago, and "Jolo" as the name for the island and its city is an artifact of that sound change. The dropping of intervocalic /1/ (sulug vs. suug) marks stylistic and dialectical variants throughout the region.

4 The same is not true of comparable ethnonyms, such as Bukid(non), Igorot, Mangyan, Dayak and Toraja used elsewhere for interior peoples of Southeast Asian Islands.

5 Outsiders, the Spanish, Americans and Christian Filipinos have frequently labelled the Tausug as "Joloano" (see note 1).

6 Pallesen, and others following him, label the linguistic group "Sama-Bajaw". Since it is necessary here carefully to distinguish the linguistic group both from the ethnic self-identification of sama and from the externally imposed and variously applied identity of "Bajao" (a spelling with "w" does not seem to do the job), I use "Samalan" for the language group, albeit with misgivings about perpetuating the form of a Tausug ethnonym samal, which they impose on the sama. The possible term "Samaan" for the language group strikes me as infelicitous. 
7 In conflicts with the Philippine military since the imposition of martial law by Marcos in 1972, the Yakan have not fared so well. The consequences for their ethnic viability are not yet clear.

8 "Kalibugan", literally in Tausug and Cebuano Bisayan "mixed, or half-breed, especially of cocks", is an attributed ethnonym loosely applied to Moslems who live in the interior of Zamboanga and practice swidden agriculture like the Subanun. Those who speak Subanun accept the ethnonym as their own in preference to local forms of "Subanun" (subanon, suban'un). Those who speak Samalan call themselves sama. Table 1 reflects these usages.

9 I am grateful to my colleague Karl Heider who found this poster for me. 